\title{
Analisis kemampuan berpikir kreatif matematis ditinjau dari kesulitan belajar siswa
}

\author{
Elva Nuranggraeni, Kiki Nia Sania Effendi, Sutirna \\ Pendidikan Matematika, Fakultas Keguruan dan Ilmu Pendidikan, \\ Universitas Singaperbangsa, Karawang, Indonesia \\ E-mail: 1610631050049@student.unsika.ac.id
}

\begin{abstract}
ABSTRAK
Tujuan dari penelitian ini adalah untuk mengetahui kemampuan berpikir kreatif matematis yang ditinjau dari kesulitan belajar siswa pada materi persegi dan persegi panjang. Sampel pada penelitian ini sebanyak 30 siswa dari kelas VII-8 dengan subjek yang diteliti sebanyak 3 siswa disalah satu sekolah menengah pertama yang berada di Kabupaten Bekasi. Pengumpulan data dengan cara menyebarkan soal tes kemampuan berpikir kreatif matematis dan wawancara dengan menggunakan bantuan aplikasi whatsapp. Penelitian ini merupakan penelitian kualitatif dengan metode penelitian studi kasus. Hasil dari penelitian menunjukkan bahwa subjek berkemampuan matematika tinggi dan sedang masih mengalami kesulitan dalam menggunakan prinsip dan kesulitan dalam memecahkan soal uraian, sedangkan subjek berkemampuan matematika rendah masih mengalami kesulitan mengemukakan konsep, kesulitan dalam menggunakan prinsip dan kesulitan dalam memecahkan soal uraian. Persentase koefisien determinasi yang diperoleh dari tes kemampuan berpikir kreatif matematis diperoleh sebesar 20\% siswa yang tergolong ke dalam kategori kelompok kemampuan tinggi, 60\% siswa tergolong ke dalam kelompok kemampuan sedang dan 20\% siswa tergolong ke dalam kelompok kemampuan rendah.
\end{abstract}

Kata Kunci: Analisis ;Berpikir Kreatif Matematis; Kesulitan Belajar.

\begin{abstract}
The purpose of this research is to find out the mathematical creative thinking ability in terms of students' learning difficulties on square and rectangular material. The sample in this study were 30 students of seventh grade junior high school students with the main subject of 3 students at one junior high school in Bekasi Regency. Data collection by distributing mathematical creative thinking ability test questions and interviews using the help of whatsapp application. This research is a qualitative research with case study research method. The results of the study indicate that subjects with high mathematical ability and are still experiencing difficulties in using principles and difficulties in solving problem descriptions, while subjects with low mathematical ability still have difficulty expressing concepts, difficulties in using principles and difficulties in solving problem descriptions. The percentage of the coefficient of determination obtained from the mathematical creative thinking ability test was obtained by $20 \%$ of students belonging to the high ability group category, 60\% of students belonging to the medium ability group and $20 \%$ of students belonging to the low ability group.
\end{abstract}

Keywords: Aanalysis; Mathematical Creative Thinking ; Difficulty Learning.

\section{PENDAHULUAN}

Matematika merupakan salah satu cabang ilmu pengetahuan yang memegang peranan penting dalam kehidupan manusia. Effendi dan Farlina, (2017) menyatakan bahwa besarnya peranan matematika dalam pendidikan karena matematika merupakan ilmu dasar yang digunakan dalam berbagai bidang keilmuan dan keterkaitan dengan kehidupan sehari-hari. Masalah matematika tidak secara otomatis menjadi kontekstual hanya dengan menyusunnya dalam bentuk cerita situasi atau menyajikannya dalam soal terapan dalam pendekatan mekanistis. Hal yang paling penting dari suatu konteks adalah bahwa konteks harus memunculkan proses matematisasi serta mendukung pengembangan pemahaman 
konseptual siswa dan kemampuan untuk mentransfer pengetahuan ke situasi baru yang relevan. Salah satu sifat yang identik dengan matematika yaitu sifat keabstrakannya.

Dalam peraturan pemerintah nomor 17 Tahun 2010 dalam Kurikulum 2013 tentang pengelolaan dan penyelenggaraan pendidikan, yang menyebutkan bahwa tujuan penyelenggaraan pendidikan dasar dan menengah yaitu membangun landasan bagi berkembangnya potensi siswa agar menjadi manusia yang berilmu, cakap, kritis, kreatif, dan inovatif (Purwaningrum, 2016). Jika kita perhatikan bahwa pendidikan di Indonesia sudah memperhatikan pengembangan kemampuan berpikir kreatif matematis siswa. Untuk mendukung tujuan pendidikan di Indonesia tersebut pembelajaran di sekolah hendaknya mampu memenuhi kebutuhan siswa untuk mengembangkan kemampuan berpikir siswa dari yang sederhana sampai yang tinggi termasuk didalamnya kemampuan berpikir kreatif.

Kreatif menurut kamus besar bahasa Indonesia ialah memiliki daya cipta atau memiliki kemampuan untuk menciptakan, sedangkan matematis ialah sangat pasti dan tepat. Sehingga dapat diartikan kemapuan berpikir kreatif matematis adalah kemampuan berpikir yang bertujuan untuk menciptakan atau menemukan ide baru yang berbeda, tidak umum, orisinil yang membawa hasil yang pasti dan tepat, Menurut Fitriarosah (2016) berpikir kreatif sangat diperlukan sesorang, karena bisa menyelesaikan suatu permasalahan bukan hanya dengan cara yang telah ada sebelumnya melainkan bisa dengan cara baru atau kombinasi baru dalam bentuk sikap atau ide maupun pokok pikiran. Sedangkan Munandar dan Supriadi (Hendriana, Rohaeti, \& Sumarmo, 2017) mengidentifikasi orang yang kreatif adalah mereka yang memiliki rasa keingintahuan yang tinggi, kaya akan idea, imajinatif, percaya diri, non-konformis, bertahan mencapai keinginannya, bekerja keras, optimistic, sensitive terhadap masalah, berpikir positif, memiliki rasa kemampuan diri, berorientasi pada masa datang, menyukai masalah yang kompleks dan menantang. Adapun indikator dari kemampuan berpikir kreatif matematis menurut Munandar (Hendriana, Rohaeti, \& Sumarmo, 2017) adalah keterampilan berpikir lancar/kelancaran (Fluency), keterampilan berpikir rinci/kelenturan (elaboration), keterampilan berpikir orisnil/keaslian (originilaty) dan ketermapilan berpikir rinci (elaborations).

Berdasarkan apa yang telah dipaparkan di atas, siswa harus mampu mengusai 4 indikator kemampuan berpikir kreatif matematis karena kemampuan berpikir kratif matematis sangat penting bagi siswa dalam pembelajaran matematika, hal ini untuk menunjang keberhasilan siswa dalam belajar matematika ataupun ilmu dibidang lainnya. Namun, pada kenyataannya banyak siswa yang masih belum menguasai kemampuan berpikir kreatif matematis dengan baik. Hal ini ditunjukkan pada studi pendahuluan yang telah di lakukan oleh peneliti yang menyatakan bahwa kemampuan berpikir kreatif matematis siswa masih rendah. Hal ini dapat dilihat dari hasil rekapitulasi jawaban keseluruhan siswa yang menunjukan nilai hasil tes kemampuan berpikir kreatif matematis siswa terdapat 6 orang siswa dengan presentase sebesar $17 \%$ yang berkategori tinggi, 24 orang siswa dengan presentase sebesar $67 \%$ yang berkategori sedang, dan 6 orang siswa dengan presentase sebesar 17\% yang berkategori rendah. Ini menunjukkan bahwa sebagian besar dari siswa berkategori rendah, dimana ini menunjukkan bahwa indikator-indikator kemampuan berpikir kreatif matematis siswa masih belum dikuasai dengan baik oleh siswa Hal ini yang peneliti temukan saat melakukan studi pendahuluan di salah satu sekolah yang berada di Kecamatan Kedung Waringin Jaya, Kelas VIII A sebanyak 36 orang siswa.

Ketidakmampuan siswa dalam memahami konsep merupakan salah satu kesulitan siswa dalam belajar matematika. Hal ini sejalan dengan apa yang di nyatakan oleh Suparno (2013) dimana Kesalahan yang berasal dari siswa dapat berupa prakonsepsi atau kesalahan konsep awal, pemikiran asosiatif, pemikiran humanistik, penalaran yang tidak lengkap atau salah, 
institusi yang salah, kemampuan dan minat belajar. Dalam menyelesaikan soal biasanya melibatkan beberapa kombinasi konsep, oleh karena itu siswa harus mampu dalam memahami konsep awalnya. Kesulitan belajar terjadi bukan hanya karena dibiarkan begitu saja oleh guru dan orang tua, melainkan dari diri siswa nya sendiri.Dalam pembelajaran matematika siswa yang mengalami kesulitan belajar masih dianggap hal yang sudah biasa oleh guru maupun orang tua. Padahal dengan membiarkan siswa dalam kesulitan belajarnya mengakibatkan kinerja otak menurun dan menyebabkan banyak siswa mengalami kesulitan dalam belajar matematika, sehingga pada akhirnya siswa tidak bisa mengikuti mata pelajaran matematika dengan baik.

Menurut Kereh, Subandar, dan Tjiang (2013), kesulitan belajar matematika dapat terjadi pada hampir setiap tahap/jenjang selama masa sekolah peserta didik, bahkan pada orang dewasa (mahasiswa). Sedangkan Supartini (Suwarto, 2013) mendefinisikan kesulitan belajar sebagai kegagalan dalam mencapai tujuan belajar, ditandai dengan tidak menguasai tingkat penguasaan minimal, tidak dapat mencapai prestasi yang semestinya, tidak dapat mewujudkan tugas-tugas perkembangan, dan tidak dapat mencapai tingkat penguasaan yang diperlukan sebagai prasyarat bagi kelanjutan untuk belajar di tingkat selanjutnya. Sejalan dengan hal tersebut, menurut Kereh, et. al. (2013), istilah kesulitan belajar dalam konten matematika dapat diartikan sebagai kesulitan peserta didik yang dapat diungkapkan dari pola kesalahan yang dibuat peserta didik dalam mengerjakan soal. Dengan tes diagnostik ditelusuri proses mental yang berlangsung pada waktu peserta didik menyelesaikan soal. Jika penyebabnya ditemukan, maka dapat diupayakan perbaikannya.

Muhaibin Syah (Sholekah, Anggreini, \& Waluyo, 2017) menyatakan bahwa fenomena kesulitan belajar seorang siswa biasanya tampak jelas dari menurunnya kinerja akademik atau prestasi belajarnya. Rendahnya tingkat keberhasilan dalam pembelajaran matematika dikarenakan beberapa alasan, diantaranya karena faktor kesulitan siswa dalam menerima materi pada pelajaran matematika dan faktor yang lain disebabkan karena ketidakmampuan siswa dalam menghubungkan suatu konsep matematika. Hal ini juga sejalan dengan apa yang di nyatkan oleh Mardianto (2012) dimana secara garis besar faktor-faktor yang menjadi penyebab timbulnnya kesulitan belajar yaitu: Faktor internal siswa, yaitu hal-hal atau keadaan yang muncul dari dalamdiri siswa sendiri, Faktor eksternal siswa, yaitu halhal atau keadaan yang datang dari luar siswa.

\section{METODE PENELITIAN}

Metode penelitian yang digunakan yaitu metode studi kasus menurut Creswell (2015) studi kasus merupakan suatu jenis pendekatan kualitatif yang menelaah sebuah "kasus" tertentu dalam konteks tau setting kehidupan nyata kontemporer. Lebih lajut Creswell (2015) menjelaskan terdapat tiga jenis penelitian studi kasus dalam hal tujuan penelitiannya yaitu studi kasus instrumental tunggal (yang berfokus pada satu isu atau persoalan tertentu), studi kasus kolektif (yang memanfaatkan beragam kasus untuk mengilustrasikan sau persoalan penting daro berbagai perspektif) dan studi kasus intrinsik (yang fokusnya adalah pada kasus itu sendiri karena unik atau tidak-biasa). Adapun dalam penelitian ini jenis penelitian studi kasus yang digunakan adalah penelitian studi kasus instrumental tunggal yang dimana telah dijelaskan sebelumnya bahwa dalam jenis penelitian ini peneliti memfokuskan pada isu atau persoalan tertentu, kemudian memilih satu kasus terbatas untuk mengilustrasikan persoalan tersebut.

Berdasarkan pendapat diatas, maka studi kasus adalah metode penelitian yang digunakan untuk menyelidiki suatu fenomena dalam kehidupan nyata secara mendalam dan cermat. 
Penelitian studi kasus ini memfokuskan pada suatu fenomena yaitu kemampuan berpikir kreatif matematis siswa ditinjau dari kesulitan belajar siswa. Adapun yang membedakan penelitian dengan pendekatan studi kasus dengan jenis pendekatan penelitian kualitatif yang lain terdapat pada kedalaman analisisnya pada sebuah kasus tertentu yang lebih spesifik. Analisis dan triangulasi data juga digunakan untuk menguji keabsahan data dan menemukan kebenaran objektif sesungguhnya.

Penelitian ini dilaksanakan pada tanggal 12 April 2020 sampai tanggal 25 April 2020. Disalah satu sekolah menengah pertama di Kabupaten Bekasi. Dalam memilih subjek dilakukan dengan cara purposive sampling dengan pengambilan subjek ini yang didasarkan pada pilihan peneliti tentang aspek apa dan siapa yang dijadikan fokus pada saat situasi tertentu selama proses penelitian, karena sampling bersifat purposive yaitu tergantung pada tujuan fokus suatu saat. Hal ini sejalan dengan Creswell (2015) yang menyatakan bahwa prosedurnya utamanya melibatkan sampling purposeful (untuk memilih kasus yang dianggap penting), yang kemudian dilanjutkan dengan analisis holisktik atas kasus tersebut melalui deskripsi detail atas pola-pola, konteks dan setting dimana kasus itu tejadi. Adapun Moleong (2017), menyatakan bahwa pada penelitian kualitatif tidak ada sampel acak, tetapi sampel bertujuan (purposive sampling) untuk menggali informasi yang menjadi dasar dari rancangan dan teori yang muncul. Oleh karena itu Teknik pengambilan subjek dalam penelitian ini adalah purposive sampling. Yang dimana proses ini bertujuan agar mendapatkan subjek utama untuk di wawancara dari 30 siswa yang sebelumnya telah mengikuti tes kemampuan berpikir kreatif matematis. Berdasarkan teori Arikunto (2013) yang menyatakan bahwa "apabila subjeknya kurang dari seratus, lebih baik diambil semua sehingga penelitiannya merupakan populasi tetapi jika jumlah subjeknya besar, dapat diambil antara $10-15 \%$ atau $15-25 \%$ atau lebih". Berdasarkan uraian diatas, peneliti akan mengambil sampel sebanyak $10 \%$ dari jumlah populasi. Populasi dalam penelitian ini sebanyak 30 peserta didik, maka jumlah yang akan diambil sebagai sampel adalah $10 \%$ x 30 = 3 siswa, penentuan kategori tersebut menggunakan standar deviasi. Hal tersebut berdasarkan dengan pendapat Arikunto (2013) yang menyatakan bahwa penentuan kategori dengan standar deviasi adalah penentuan kedudukan dengan membagi kelas pada setiap kelompok (tinggi, sedang, dan rendah). Sehingga diperoleh banyaknya siswa yang diambil sebagai subjek berjumlah 3 siswa dari masing-masing kelompok kemampuan berpikir kreatif matematis berkategori tinggi, sedang, dan rendah.

\section{HASIL DAN PEMBAHASAN}

Berdasarkan hasil penyebaran soal tes kemampuan berpikir kreatif matematis yang dilakukan secara online dengan bantuan aplikasi whatsapp. Diperoleh adalah data berupa nilai siswa pada kemampuan berpikir kreatif matematis siswa dalam mengerjakan soalsoal berupa soal tes uraian dengan materi sistem persamaan linear satu variabel dan sistem pertidaksamaan linear satu variabel.

Diperoleh skor tertinggi 4 dan skor terendah 0 dengan skor rata-rata 47,08 dan standar deviasi 21,63. Standar deviasi sendiri dapat digunakan untuk melihat seberapa jauh simpangan data dari skor rata-ratanya, semakin kecil simpangan maka data semakin homogen. Sehingga dari hasil analsis data di atas dapat digunakan sebagai salah satu acuan dalam penentuan jumlah subjek dalam tiap kelompok kemampuan. Adapun dari hasil analisis data tes kemampuan berpikir kreatif matematis yang diikuti oleh 30 siswa, dapat ditentukan jumlah siswa yang termasuk ke dalam kelompok kategori tinggi, sedang, dan rendahnya dengan ketentuan yang diperoleh dengan menggunakan standar deviasi berdasarkan pendapat dari Arikunto (2013) yang menyatakan penentuan kedudukan dengan membagi 
kelas pada setiap kelompok (tinggi, sedang, rendah) merupakan penentuan kategori dengan menggunakan standar deviasi. Pada kemampuan berpikir kreatif matematis terdapat 6 siswa pada kategori tinggi, 18 siswa pada kategori sedang dan 6 siswa pada kategori rendah. Gambar 1 menunjukkan perbandingan porsi ketiga kategori tersebut

\section{Persentase kemampuan berpikir $\underset{\square \text { Tinggi }}{\text { kreatif }} \underset{\square \text { Sedang }}{\text { matemdah }}$}

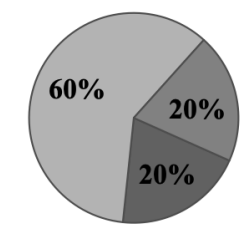

Gambar 1. Presentasi Hasil Analisis Data Tes

Berdasarkan Gambar 1. terlihat bahwa 30 siswa yang ikut melaksanakan tes kemampuan berpikir kreatif matematis diperoleh bahwa terdapat 20\% siswa yang tergolong ke dalam kategori kelompok kemampuan tinggi, 60\% siswa tergolong ke dalam kelompok kemampuan sedang dan 20\% siswa tergolong ke dalam kelompok kemampuan rendah, yang kemudian dipilih 1 orang siswa pada setiap kategori yang memiliki nilai terbesar pada kelompok kategorinya sebagai subjek penelitian untuk kemudian dianalisis lebih dalam mengenai kemampuan berpikir kreatif matematis ditinjau dari kesulitan belajar. Kemudian, peneliti melakukan wawancara dengan subjek yang telah terpilih untuk memperkuat analisis hasil jawaban siswa tentang kemampuan berpikir kreatif matematis ditinjau dari kesulitan belajar. Klasifikasi kemampuan kreatif ditinjau dari kesulitas belajar ditampilkan pada Tabel 1.

Tabel 1 Klasifikasi Kemampuan Berpikir Kreatif Matematis Ditinjau dari Kesulitan Belajar siswa

\begin{tabular}{llll}
\hline \multirow{2}{*}{$\begin{array}{l}\text { Indikator } \\
\text { Kemamapuan }\end{array}$} & \multicolumn{3}{l}{ Jenis Kesulitan Siswa Berdasarkan Kategori Kemampuan } \\
\cline { 2 - 4 } & Tinggi & Sedang & Rendah \\
\hline Lancar (Fluency) & 2 & $1,2,3$ & $1,2,3$ \\
\hline Luwes Flexibility) & 3 & $1,2,3$ & $1,2,3$ \\
\hline Asli (Originality) & 3 & 3 & $1,2,3$ \\
\hline Rinci (Elaboration) & 3 & 1 & 1,3 \\
\hline
\end{tabular}

Keterangan :

1 : Kesulitan belajar dalam mengemukakan konsep

$2 \quad$ : Kesulitan belajar dalam menggunakan prinsip

3 : Kesulitan belajar dalam memecahkan soal uraian

Berdasarkan hasil tes dari siswa yang telah dipilih sebagai subjek penelitian, berikut adalah analisis jawaban tes uraian kemampuan berpikir kreatif matemtis siswa dengan indikator berpikir lancar (fluency).

Di bawah ini terdapat 2 persegi besar yang berukuran sama dengan panjang sisi 7 satuan dan 4 persegi kecil yang berukuran sama dengan panjang sisi 3 satuan. Jika bangun yang diarsir dalam salah satu persegi besar adalah sebuah persegi pula, maka berapa satuan kuadrat luas bangun persegi ABCD yang diarsir tersebut? dan buatlah penyelesaian paling sedikit dengan tiga cara! 


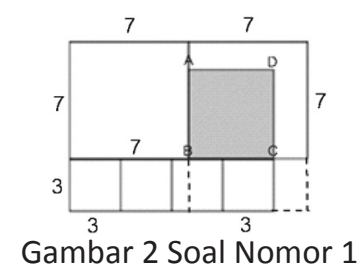

Adapun jawaban serta solusi yang digunakan oleh siswa untuk menjawab soal nomor 1 . Jawaban yang diberikan oleh siswa diperkuat dengan penjelasan siswa melalui kegiatan wawancara, jawaban dan hasil wawancara ini wawancara untuk memperkuat analisis hasil jawaban siswa tentang kemampuan berpikir kreatif matematis ditinjau dari kesulitan belajar.

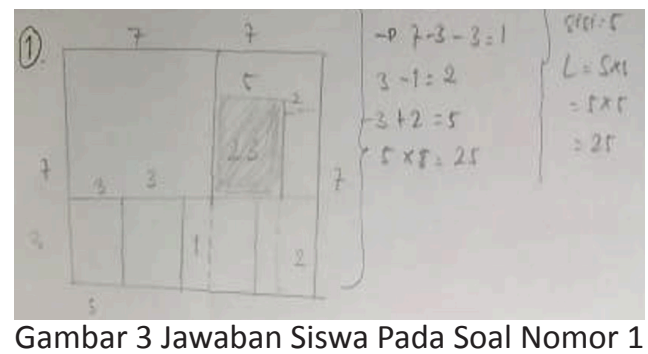

Berdasarkan hasil dari penyelesaian pada Gambar 3 terlihat bahwa siswa kurang memahami permasalahan dari soal tersebut, itu dapat terlihat dari cara penyelesaian siswa yang tidak beraturan. Adapun dari setiap cara yang dituliskan siswa sudah memenuhi kriteria dari pedoman pensekoran berpikir lancar yakni siswa dapat memberikan sebuah ide/gagasan namun tidak relevan. Hal itu dibuktikan dengan penyelesaian soal pada cara pertama dimana siswa terlebih dahulu menggambarkan banyak persegi yang ada pada soal yang kemudian siswa menuliskan satuan-satuan yang sudah diketahui sehingga siswa dapat menentukan satuan kuadrat yang di inginkan yaitu $7-3-2=1,3-1=2,2+3=5$ dan $5 \times 5=25$ yang dimana hasil yang di peroleh siswa pada penyelesaian soal tersebut memang sudah sesuai namun siswa tidak memberikan penjelasan yang rinci mengapa bisa mengambil angka tersebut. Dan juga siswa tidak membuat gambar persegi pada cara 2 dimana siswa hanya menuliskan hasil satuan kuadrat seperti cara 1 yang kemudian hanya mensubstitusikannya kedalam rumus tanpa penjelasan yang rinci.

Selain analisis jawaban siswa diatas, terdapat beberapa temuan dari hasil yang menunjukkan kesulitan yang paling menonjol ada pada kelompok rendah, dimana siswa yang mewakili kelompok tersebut menyatakan bahwa siswa merasa kesulitan dalam mengerjakan soal yang diberikan karena tidak dapat mengingat rumus yang tersedia yang dimana hal tersebut bisa diatasi ketika siswa mampu memahami konsep dari materi yang diajarkan akan tetapi karena siswa tidak memahami konsep yang sebenarnya maka siswa akan kesulitan dalam mengemukakan konsep tersebut sehingga siswa hanya akan mampu mengerjakan soal yang diberikan ketika siswa meningat rumus dari materi tersebut. Hal ini didukung berdasarkan hasil penelitian Permatasari, Setiawan, Kristiana (2015) yang menyimpulkan bahwa kesulitan siswa yang tinggi terdapat pada indikator menyatakan ulang sebuah konsep, mengaplikasikan konsep atau algoritma ke pemecah masalah. Dengan penyebab kesulitan tersebut karena siswa tidak menguasai konsep siswa pun sering keliru ketika mengerjaka soal, hal itu pun terjadi karena siswa tidak memahami dengan benar dari konsepnya. Hal ini juga didukung berdasarkan hasil penelitian Abdurrahman (2012) yang menyatakan bahwa selain kesulitan, siswa juga mengalami kekeliruan dalam menyelesaikan soal. Beberapa kekeliruan umum yaitu kekurangan pemahaman tentang simbol, nilai tempat, perhitungan, penggunaan proses yang keliru, dan tulisan yang tidak terbaca. 
Berikutnya hasil dari analisis dan wawancara yang telah dilakukan kepada setiap subjek diperoleh bahasan dalam kesulitan dalam menggunakan prinsip pada setiap indikator kemampuan berpikir kreatif matematis diantaranya indikator berpikir lancar (fluency), berpikir luwes (flexibility), berpikir original (originality) dan berpikir rinci (elaboration). Dari hasil analisis dan wawancara yang telah dilakukan kepada siswa lain juga diperoleh bahwa siswa akan mampu menggunakan prinsip dari materi tersebut apabila konsepnya sudah ia kuasai, sedangkan untuk menerapka prinsip tersebut akan lebih mudah ketika masih bisa diibaratkan atau dicontohkan dengan bentuk nyata. Adapun hasil analisis dan wawancara yang telah dilakukan kepada siswa diperoleh bahwa sesuatu yang siswa kerjakan harus sesuai denga kemampuannya, apabila kemampuan siswa hanya dengan menggunakan rumus yang tersedia maka siswa menggunakan itu saja, karena menurut siswa untuk menggunakan dan menerapkan prinsip yang berkesinambungan dari konsep itu sulit.

Sedangkan hasil analisis dan wawancara yang telah dilakukan kepada siswa dari kelompok rendah diperoleh bahwa siswa hanya mampu mengerjakan soal denga rumus yag tersedia saja tanpa menggunakan prinsip maupun menerpkannya. Sejalan dengan apa yang telah diperoleh dari masing-masing subjek, hal ini juga didukung berdasarkan hasil penelitian Abrar (2014) menyatakan bahwa wujud dari kesulitan siswa dalam menggunakan prinsip antara lain: (1) Tidak mampu melakukan kegiatan penemuan tentang sesuatu dan teliti dalam melakukan perhitungan atau operasi aljabar. (2) Ketidakmampuan siswa untuk menentukan faktor yang relevan dan akibatnya tidak mampu mengabstraksikan pola-pola. (3) Siswa dapat menyatakan suatu prinsip tetapi tidak dapat mengutarakan artinya dan tidak dapat menerapkan prinsip tersebut. Dan untuk analisis kesulitan belajar yang terakhir diperoleh bahwa siswa akan mampu memecahkan soal uraian apabila intruksi dari soal tersebut jelas , namun yag sering didapatkan siswa ketika membaca soal uraian adalah siswa kesulitan memahami maksud dari soal tersebut dimana siswa tidak sadar jika perintah dari soal tersebut adalah menyelesaikannya dengan lebih dari satu cara., hal ini juga didukung berdasarkan hasil penelitian Sudirman, Cahyono, \& Kadir (2019) yang menyatakan bahwa siswa kesulitan dalam mengerjakan soal cerita disebabkan karena siswa kurang cermat dalam membaca dan memahami kalimat demi kalimat serta mengenai apa yang diketahui dalam soal dan apa yang ditanyakan, serta bagaimana cara menyelesaikan soal secara tepat.

\section{SIMPULAN DAN SARAN}

Penelitian ini menyimpulkan bahwa kelompok pada kategori sedang mendominasi $60 \%$ dari banyaknya siswa, sementara kelompok tinggi dan sedang masing-masing hanya sebesar $20 \%$. Hal ini berarti siswa sudah cukup baik dalam mengungkapkan penyelesaiannya secara kreatif. Kesulitan belajar siswa pada materi persegi dan persegi panjang dapat dilihat dari kesulitan-kesulitan siswa dalam mengerjakan soal. Ada tiga kesulitan siswa yang ditemukan yaitu seperti kesulitan mengemukakan konsep, bagi siswa apabila sejak awal siswa tidak mengerti akan maksud dan konsep dari materi yang diberikan maka seterusnya siwa akan merasa kesulitan ketika mengerjakan soal sehingga akan menyulitkan siswa untuk berpikir secara kreatif. Sedangkan pada kesulian belajar kedua yaitu kesulitan belajar dalam menggunakan prinsip, siswa juga akan kesulitan karena ketika konsep dari materi tidak dimengerti maka prinsip dari materi tersebut juga tidak dapat ditemukan oleh siswa sehingga ketika menjawab permasalahan yang diberikan siswa tidak mampu menyesuaikannya dengan baik. Dan untuk kesulitan belajar berikutnya adalah kesulitan dalam memecahkan soal uraian, ini adalah hal yang sulit bagi siswa karena menurut siswa soal dalam bentuk uraian sulit dimengerti. Adapun saran yang dapat diberikan penulis untuk 
peneliti lain adaah perlu dilakukan penelitian lebih lanjut untuk mengetahui faktor-faktor penyebab kesulitan belajar sisiwa berdasarkan kesulitan dalam mengemukakan konsep, kesulitan dalam menggunakan prinsip dan kesulitan dalam memecahkan soal uraian.

\section{DAFTAR RUJUKAN}

Abdurrahman. (2012). Pendidikan Bagi Anak Berkesulitan Belajar. Jakarta, Indonesia: Rineka Cipta

Abrar, A. I. P. (2014). Kesulitan siswa SMP belajar konsep dan prinsip dalam matematika. AlKhwarizmi: Jurnal Pendidikan Matematika dan Ilmu Pengetahuan Alam, 2(1), 59-68. DOI: 10.24256/jpmipa.v2i1.102

Arikunto, S. (2013). Prosedur Penelitian Suatu Pendekatan Praktik. Jakarta, Indonesia: Rineka Cipta.

Creswell. (2015). Penelitian Kualitatif \& Desain Riset: Memilih di antara Lima pendekatan. Yogyakarta, Indonesia: Pustaka Pelajar.

Effendi, K.N., \& Farlina, E. (2017). Kemampuan Berpikir Kreatif Siswa SMP kelas VII dalam Penyelesaian Masalah Statistika. Jurnal Analisa, 3(2), 130-137. DOI: 10.15575/ ja.v3i2.2013

Fitriarosah, N. (2016). Pengembangan Instrumen Berpikir Kreatif Matematis Untuk Siswa SMP. In Prosiding Seminar Nasional Pendidikan Matematika Volume 1 (pp. 243-250). Retrieved from $\underline{\mathrm{http}: / / \text { repository.unikama.ac.id/840 }}$

Kereh, C. T., Sabandar, J., \& Tjiang, P. C. (2013). Identifikasi kesulitan belajar mahasiswa dalam konten matematika pada materi pendahuluan fisika inti. In Mahatma, T., Sutresno, A., \& Kurnianingsih, D. (Eds.) Proceedings of Seminar Nasional Sains dan Pendidikan Sains VIII, Fakultas Sains dan Matematika, UKSW Salatiga (Vol. 4, No. 1, pp. 10-17). Retrieved from http://repository.uksw.edu/handle/123456789/3113

Mardianto. 2012. Psikologi Pendidikan. Medan, Indonesia: Perdana.

Moleong, L. J. (2016). Metodoligi Penelitian Kualitatif. Bandung, Indonesia: Remaja Rosdakarya.

Sholekah, L. M., Anggreini, D., \& Waluyo, A. (2017). Analisis kesulitan siswa dalam menyelesaikan soal matematika ditinjau dari koneksi matematis materi limit fungsi. Wacana Akademika: Majalah Ilmiah Kependidikan, 1(2), 151-164. DOI: 10.30738/ wa.v1i2.1413

Hendriana, H., Rohaeti, E. E., \& Sumarmo, U. (2017). Hard skills dan soft skills matematik siswa. Bandung, Indonesia: Refika Aditama.

Permatasari, B. A. D., \& Kristiana, A. I. (2015). Analisis Kesulitan Siswa dalam Menyelesaikan Soal Materi Aljabar Siswa Kelas VIII SMP Negeri 2 Bangil. Kadikma, 6(2), 119-130. Retrieved from https://jurnal.unej.ac.id/index.php/kadikma/

Purwaningrum, J. P. (2016). Mengembangkan kemampuan berpikir kreatif matematis melalui discovery learning berbasis scientific approach. Refleksi Edukatika: Jurnal Ilmiah Kependidikan, 6(2), 145-157. DOI: 10.24176/re.v6i2.613

Sudirman, Cahyono, E., \& Kadir. (2019). Analisis Kemampuan Koneksi Matematis Siswa SMP Pesisir Ditinjau Dari Perbedaan Gender. Jurnal Pembelajaran Berpikir Matematika (Journal of Mathematics Thinking Learning), 3(2), 11-22. DOI: 10.33772/jpbm. v3i2.5729

Suparno, P. (2013). Miskonsepsi \& perubahan konsep dalam pendidikan fisika. Jakarta, Indonesia: Grasindo.

Suwarto, D. (2013). Pengembangan Tes Diagnostik Dalam Pembelajaran. Yogyakarta, Indonesia: Pustaka Pelajar. 